\title{
Solar Assisted Fast Pyrolysis: A Novel Approach of Renewable Energy Production
}

\author{
Mohammad U. H. Joardder, ${ }^{1,2}$ P. K. Halder, ${ }^{3}$ A. Rahim, ${ }^{1}$ and N. Paul ${ }^{4}$ \\ ${ }^{1}$ Rajshahi University of Engineering and Technology, Rajshahi 6204, Bangladesh \\ ${ }^{2}$ Science and Engineering Faculty, Queensland University of Technology, Brisbane, QLD 4001, Australia \\ ${ }^{3}$ Department of Industrial and Production Engineering, Jessore University of Science and Technology, Jessore 7408, Bangladesh \\ ${ }^{4}$ Bangladesh University of Engineering and Technology, Dhaka 1000, Bangladesh
}

Correspondence should be addressed to Mohammad U. H. Joardder; muhjoardder@gmail.com

Received 3 May 2014; Revised 17 July 2014; Accepted 22 July 2014; Published 18 August 2014

Academic Editor: Dmitry Murzin

Copyright (C) 2014 Mohammad U. H. Joardder et al. This is an open access article distributed under the Creative Commons Attribution License, which permits unrestricted use, distribution, and reproduction in any medium, provided the original work is properly cited.

\begin{abstract}
Biofuel produced by fast pyrolysis from biomass is a promising candidate. The heart of the system is a reactor which is directly or indirectly heated to approximately $500^{\circ} \mathrm{C}$ by exhaust gases from a combustor that burns pyrolysis gas and some of the byproduct char. In most of the cases, external biomass heater is used as heating source of the system while internal electrical heating is recently implemented as source of reactor heating. However, this heating system causes biomass or other conventional forms of fuel consumption to produce renewable energy and contributes to environmental pollution. In order to overcome these, the feasibility of incorporating solar energy with fast pyrolysis has been investigated. The main advantages of solar reactor heating include renewable source of energy, comparatively simpler devices, and no environmental pollution. A lab scale pyrolysis setup has been examined along with $1.2 \mathrm{~m}$ diameter parabolic reflector concentrator that provides hot exhaust gas up to $162^{\circ} \mathrm{C}$. The study shows that about $32.4 \%$ carbon dioxide $\left(\mathrm{CO}_{2}\right)$ emissions and almost one-third portion of fuel cost are reduced by incorporating solar heating system. Successful implementation of this proposed solar assisted pyrolysis would open a prospective window of renewable energy.
\end{abstract}

\section{Introduction}

Congruency between demand and supply of energy is the measure of a country's development index. There is a close relationship between the level of energy consumption in a country and its economic development. The energy crisis is the major problem in today's world due to rapid depletion of nonrenewable energy resources like fossil fuels, oils, and natural gases as the energy demand is growing at an alarming rate [1]. Likewise, Bangladesh has been facing a severe energy crisis for decades as energy is necessary for almost all economic activities ranging from irrigation to the manufacture of goods. Recently, the country's proven probable natural gas reserves are estimated to be approximately $195400000000 \mathrm{~m}^{3}$ [2] while the present coal reserves in the country are about 2041 million tons [3]. An estimation shows that total petroleum products (diesel, kerosene, petrol, and octane) storage in the country is about 687500 tons which account for only $8 \%$ of the total demand [4]. It is estimated that the energy demand would increase by five times the current demand by the year 2100 as the world population is expected to be more than 12 billion [5]. In Bangladesh, the reserves of commercial primary energy sources (e.g., natural gas and coal) are not adequate to fulfill the increasing demand of the country [6]. Power generation in the country is mainly dependent on natural gas and accounts for $62.16 \%$ of the total installed electricity generation capacity (10416 MW) in June 2014 [7]. Thus, the attention has been given to renewable energy over the last few years, especially after global awareness.

Pyrolysis is considered to be the prominent method to extract renewable energy (biooil) from different kinds of biomass including agricultural residues, forest residues, and municipal waste. Pyrolysis, a thermal decomposition process of organic components in biomass wastes in absence of oxygen at mediate temperature (about $500^{\circ} \mathrm{C}$ ), provides yield products tar (biooil, biofuel, and biocrude), char (activated carbon), and gaseous fractions (fuel gases) [8]. Pyrolysis processes can be categorized as slow pyrolysis and fast 
pyrolysis on the basis of time it takes to complete thermal decomposition of the feed materials. Fast pyrolysis is widely used as it takes seconds to complete decomposition of biomass and produces about $60 \%$ of yield as biooil whereas slow pyrolysis results in biochar as the main product and takes several hours to complete [9]. However, the particle size of feedstocks affects the efficiency and nature of the pyrolysis process. Furthermore, pyrolysis may be either fixed bed pyrolysis or fluidized bed pyrolysis. In fixed bed pyrolysis, a fixed bed pyrolyzer is used where the feed material is fixed in the reactor and heated at elevated temperature. It is necessary to use inert gas (usually nitrogen) to make inert condition and to dispose gaseous mixture into the condenser. A possible pathway of pyrolysis process is shown in Figure 1.

This technology is spreading with research and experimental work in many countries of the present world [10]. Biomass can be used as raw material for pyrolysis to generate liquid, gaseous, and solid fuels. Pyrolysis conversion technology for biomass has been investigated over the last three decades and is used commercially [11]. The technology produces gas, vapor, and solid char; however the proportion of the yield products depends on types and properties of feed materials and process conditions [10]. Solid char with a gross calorific value (GCV) of 17-36 MJ/kg may be used to provide heat for pyrolysis process itself, as a fuel either directly as briquettes or as char-oil and as feedstock to prepare activated carbon. The pyrolysis gas fraction comprises $\mathrm{CO}_{2}, \mathrm{CO}, \mathrm{H}_{2}$, $\mathrm{CH}_{4}, \mathrm{C}_{2} \mathrm{H}_{4}, \mathrm{C}_{3} \mathrm{H}_{6}$, and hydrocarbons with a GCV of 6.4$9.8 \mathrm{MJ} / \mathrm{kg}$ that can be used for process heat [12]. Therefore, the cost of heating system can be reduced by utilization of the char and gas products in the pyrolysis process. Agricultural waste and municipal solid, the members of biomass, are considered as attractive renewable energy resource due to its zero net carbon dioxide emission to the atmosphere [13]. Pyrolysis oil derived from agricultural wastes of GCV ranging from 15 to $38 \mathrm{MJ} / \mathrm{kg}$ has some advantages in transportation, storage, combustion, retrofitting, and flexibility in production and marketing [14]. The liquid product is useful as a fuel in turbine and other heating systems and it can be added to petroleum refinery feedstock or upgraded by catalysts to produce petroleum grade refined fuels [15]. It is worthy to mention that biooil derived from biomass, which is a mixture of about 300 types of major and minor organic compounds (i.e., acids, alcohols, ketones, aldehydes, phenols, ethers, esters, sugars, furans, nitrogen compounds and multifunctional compounds, etc.), has several environmental advantages over fossil fuels as a clean fuel [16]. Moreover, biooil would not be subjected to $\mathrm{SO}_{x}$ taxes as biomass contains insignificant amounts of sulfur and generates more than $50 \%$ lower $\mathrm{NO}_{x}$ than diesel oil. In addition, in 2005, UN Food and Agriculture Organization has estimated that about 1.67 billion tons of dates were produced in top ten date producer countries. This huge amount of seeds is almost unutilized and rarely used for horses, cattle, camels, sheep, and goats feed. Thus, this waste may be used effectively as feed material for energy recovery as fuel due to its nonfood and other noncommercial uses. However, the high expense and complexity as well as environmental threat are the major challenges of conventional biomass and electrical heating system of pyrolysis

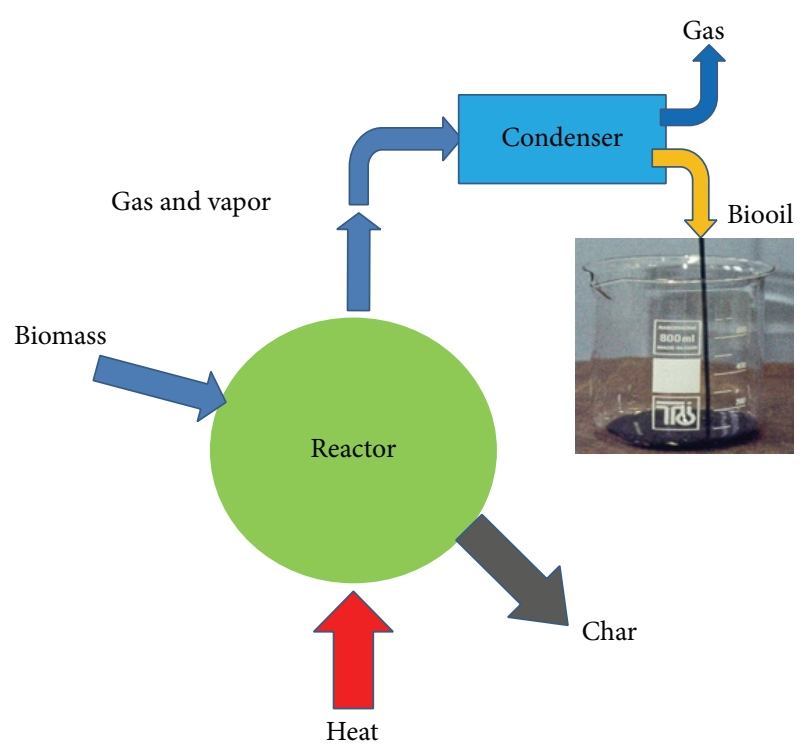

FIGURE 1: A possible pathway of pyrolysis of organic solid waste.

technology. Therefore, a new concept of solar heating is assimilated to the biomass heating system to mitigate the problems. In this study, the reactor was heated partially to $162^{\circ} \mathrm{C}$; however continuous heating may be more effective to mitigate emission from biomass fuel as well as cost of fuel.

\section{Solar Assisted Pyrolysis: Classification and Design}

Although pyrolysis process is a prominent candidate of renewable energy, it has some shortcomings. Among the challenges of pyrolysis system, diminishing energy supply as it takes other sources of energy to heat the reactor and global warming are prominent. Biooil derived from the biomass waste can be considered as an alternative to fossil fuels because they are sustainable and almost $\mathrm{CO}_{2}$ neutral although the production of heat causes additional pollution during pyrolysis process. Reactor, the heart of pyrolysis system, is heated to elevated temperatures by external biomass heater or internal electrical heater. Extensive heat energy, specially, is required to decompose the biomass waste. These heating systems are very costly and also the combustion of biomass fuels generates huge amount of $\mathrm{CO}_{2}$ responsible for environmental pollution. In addition to this, the biomass or electrical heater makes the reactor more complex system.

This problem of pyrolysis system can be eliminated by incorporating a solar heating system. The combined solar and biomass heating system can be very effective for this purpose. This solar assisted paralysis system is more environment friendly and energy efficient. In this process, the feed material is fed into the reactor and heat is applied externally by the parabolic solar heater. A conceptual solar assisted pyrolysis system is shown in Figure 2 along with solar heating. Feed supply is controlled by control valve instead of fluidize system to relieve a controlled fixed bed pyrolysis with a few intermittent criteria. 


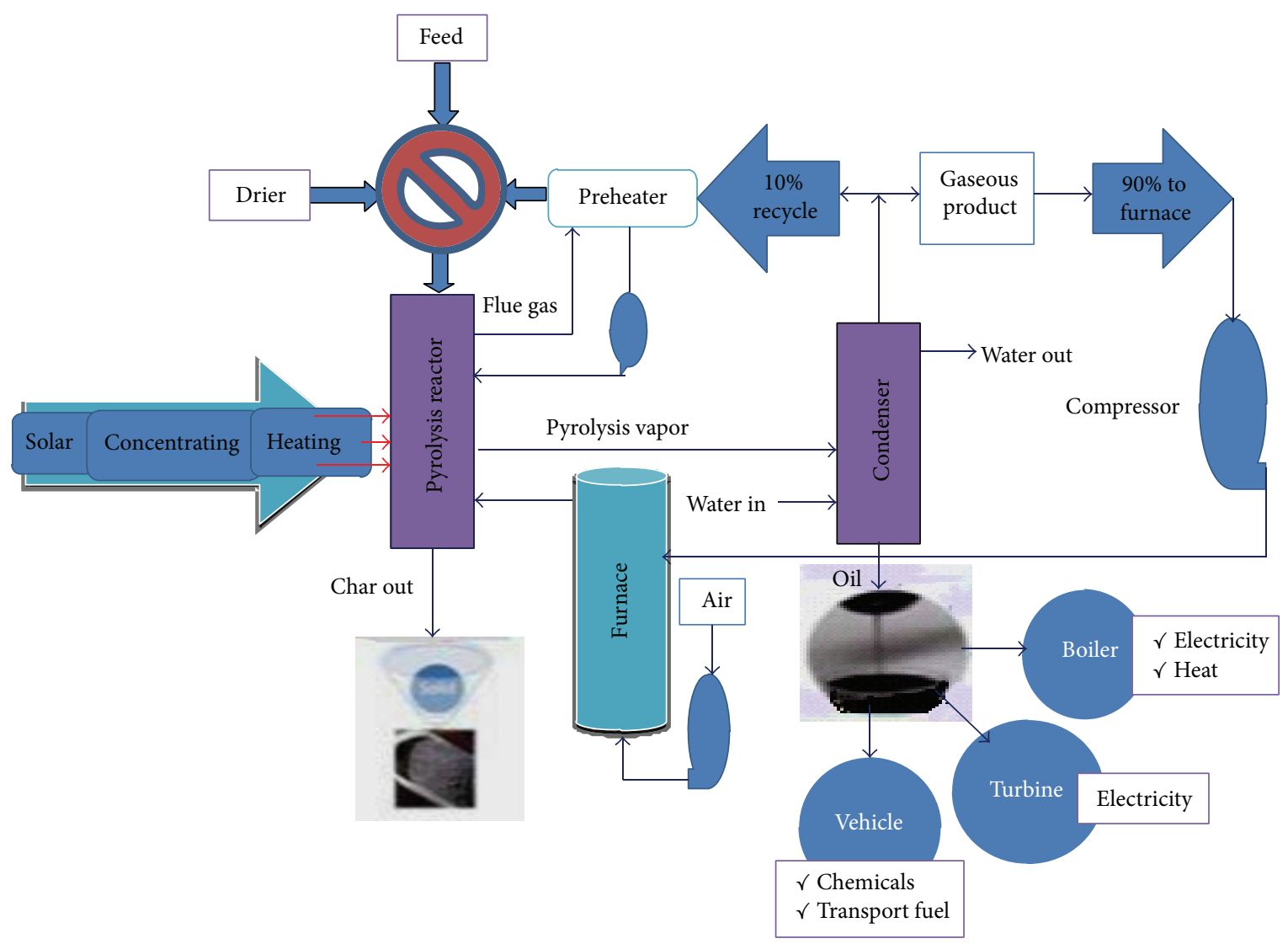

FIGURE 2: Conceptual solar fast pyrolysis system for commercial purpose.

2.1. Classification of Solar Assisted Pyrolysis. The problem of heating system of pyrolysis is the main issue since its invention. The conventional external biomass heating system contributes to air pollution through huge amount of $\mathrm{CO}_{2}$ released from its burning. On the other hand, the internal electrical heating system is a very expensive option. Therefore, it will be better practice to assimilate solar heating along with biomass heating or electrical heating system to reduce heating cost as well as pollution. However, it is difficult to obtain optimum temperature for pyrolysis using only solar heating system. As this approach is still in embryonic stage, it needs extensive research and investigation of design and implementation in commercial scale. However, solar assisted pyrolysis can be classified as partial heating and continuous heating by solar energy, as shown in Figure 3. In partial heating, initially the reactor is heated up to a certain temperature by solar heating system and then by biomass or electrical heating system. On the contrary, the reactor is heated continuously by solar heating system with biomass or electrical heating system throughout the pyrolysis cycle in continuous heating. It may be also possible to heat the reactor by using only solar heat, but it is subjected to intensive attention on the solar heating system.

2.2. Solar Assisted Pyrolysis Reactor Design Consideration. Design of reactor is the vital part of any kind of pyrolysis system. In case of solar assisted pyrolysis it is also important to design the reactor. As we mentioned, the reactor for this system is simpler than the other conventional reactor of pyrolysis; however there still exists a difficulty to obtain uniform heating throughout the reactor surface for both intermitted and continuous solar assisted heating. A conceptual design of continuous solar heating system with rotating reactor and sliding solar concentrator is illustrated in Figure 4. This system will heat up the reactor evenly and raise the temperature of feed material to optimum temperature uniformly for decomposition.

\section{Prospects of Solar Energy and Pyrolysis in Bangladesh: An Investigation}

In order to validate the proposed pyrolysis system, an experimental investigation has been conducted where we consider the solar energy availability in Bangladesh. In the following section a brief discussion of solar and pyrolysis prospect followed by experimental investigation has been presented.

3.1. Solar Energy Prospect. Bangladesh is endowed with the enormous supplies of solar energy. Bangladesh has the location between $20.308^{\circ}$ and $26.388^{\circ}$ north latitude and $88.048^{\circ}$ and $92.448^{\circ}$ east longitude with an area of $147500 \mathrm{sq} \cdot \mathrm{km}$, which is an ideal location for the best utilization of solar energy [17]. The solar map of Bangladesh provided by the 


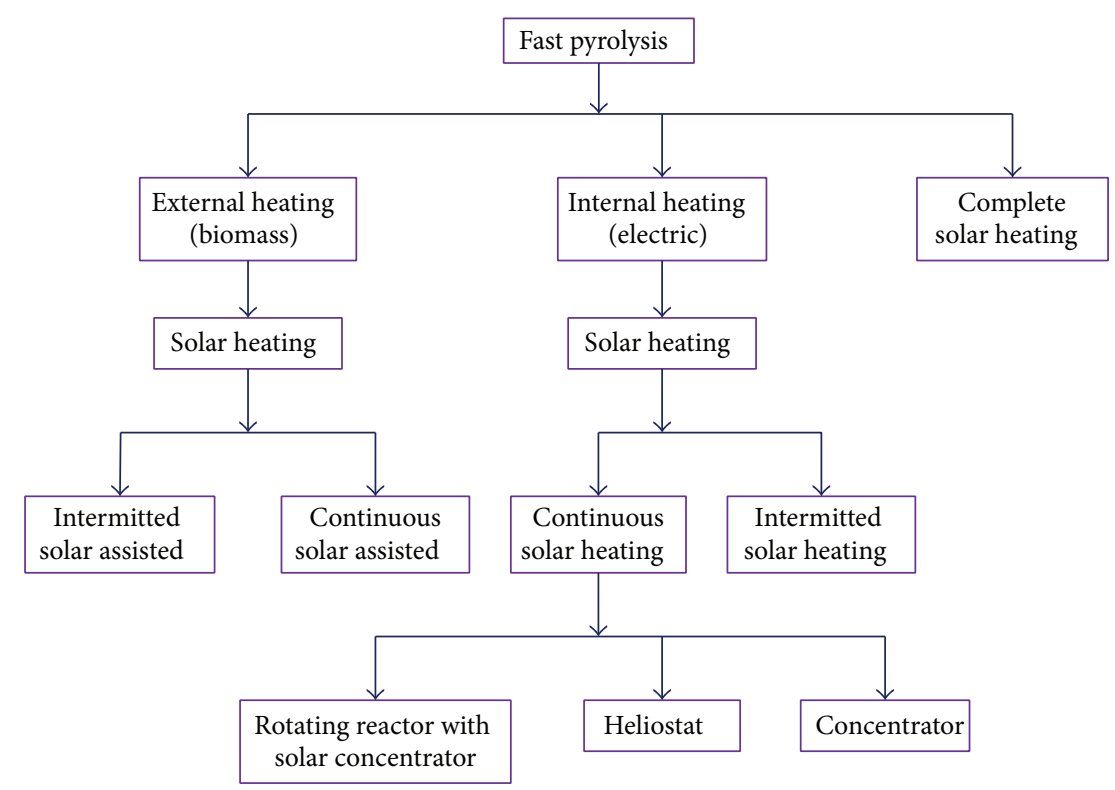

FIGURE 3: Classification of solar (assisted) fast pyrolysis.

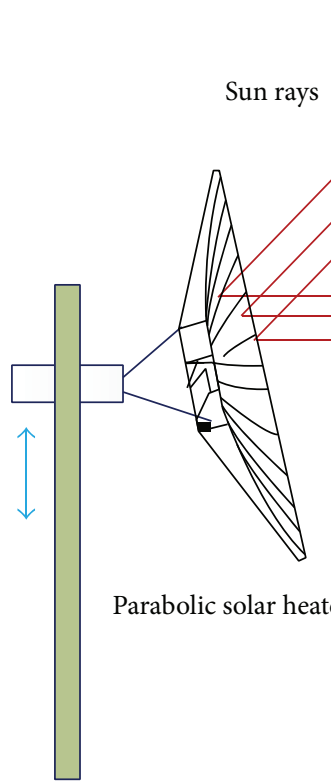

Figure 4: Complete solar fast pyrolysis with rotating reactor and sliding solar concentrator concept.

Geospatial Toolkit shows that the solar radiation is in the range of $4-5 \mathrm{kWh} / \mathrm{m}^{2} /$ day on about $94 \%$ surface areas of Bangladesh $[17,18]$. The average of sunny hours per day in Bangladesh is 6.5 , and also the annual mean solar radiation is about $0.2 \mathrm{~kW} / \mathrm{m}^{2}$. This statistics shows that Bangladesh theoretically receives approximately $69751 \mathrm{TWh}$ of solar energy in every year, which was more than 3000 times higher than the electricity generation in fiscal year 2006 in the country. It is found that the average annual power density of solar radiation in Bangladesh is typically in the range of $100-300 \mathrm{~W} / \mathrm{m}^{2}$ [19].
3.2. Pyrolysis in Bangladesh. Pyrolysis technology is in developing stage in Bangladesh; however the feasibility study of this technology is possible for production of alternative liquid fuel from organic solid wastes. Some research works in this field have been continuing in Rajshahi University of Engineering and Technology (RUET) since 2000. A numerous studies show the feasibility test of pyrolysis of different waste biomass seeds, waste plastic, municipal solid wastes, scrap tire, and lingo-cellulosic materials [20-34]. A recent study proposes that the medium commercial scale plant using waste tire material is favorable, with better techno-economics. This plant will reduce the annual energy import by 29400 tons (205000 barrels) of oils and 22400 tons of coal. Moreover, a big amount of hazardous waste (used tires) would be managed properly [35].

\subsection{Materials and Methods}

3.3.1. Materials. Sample date seed for pyrolysis is collected locally in Rajshahi, Bangladesh. The feedstock is ground and cut into three different volume sizes of $0-0.2 \mathrm{~cm}^{3}, 0.2-.4 \mathrm{~cm}^{3}$, and $0.4-0.6 \mathrm{~cm}^{3}$. Then the sample is dried in oven for 24 hours at $110^{\circ} \mathrm{C}$ to remove moisture prior to pyrolysis. The proximate and ultimate analysis of date seed is presented in Table 1.

3.3.2. Experimental Setup. Pyrolysis is done in an externally heated stainless steel fixed bed reactor system. The main components of the solar pyrolysis system are fixed bed reactor, parabolic solar reflector, biomass heater, liquid condenser, and ice cooled liquid collectors. The schematic diagram of the fixed bed pyrolysis system is shown in Figure 5. The reactor can be heated externally by the parabolic solar heater along with biomass heating system. The reflected solar rays from the parabolic solar heater that can be used as a heat 


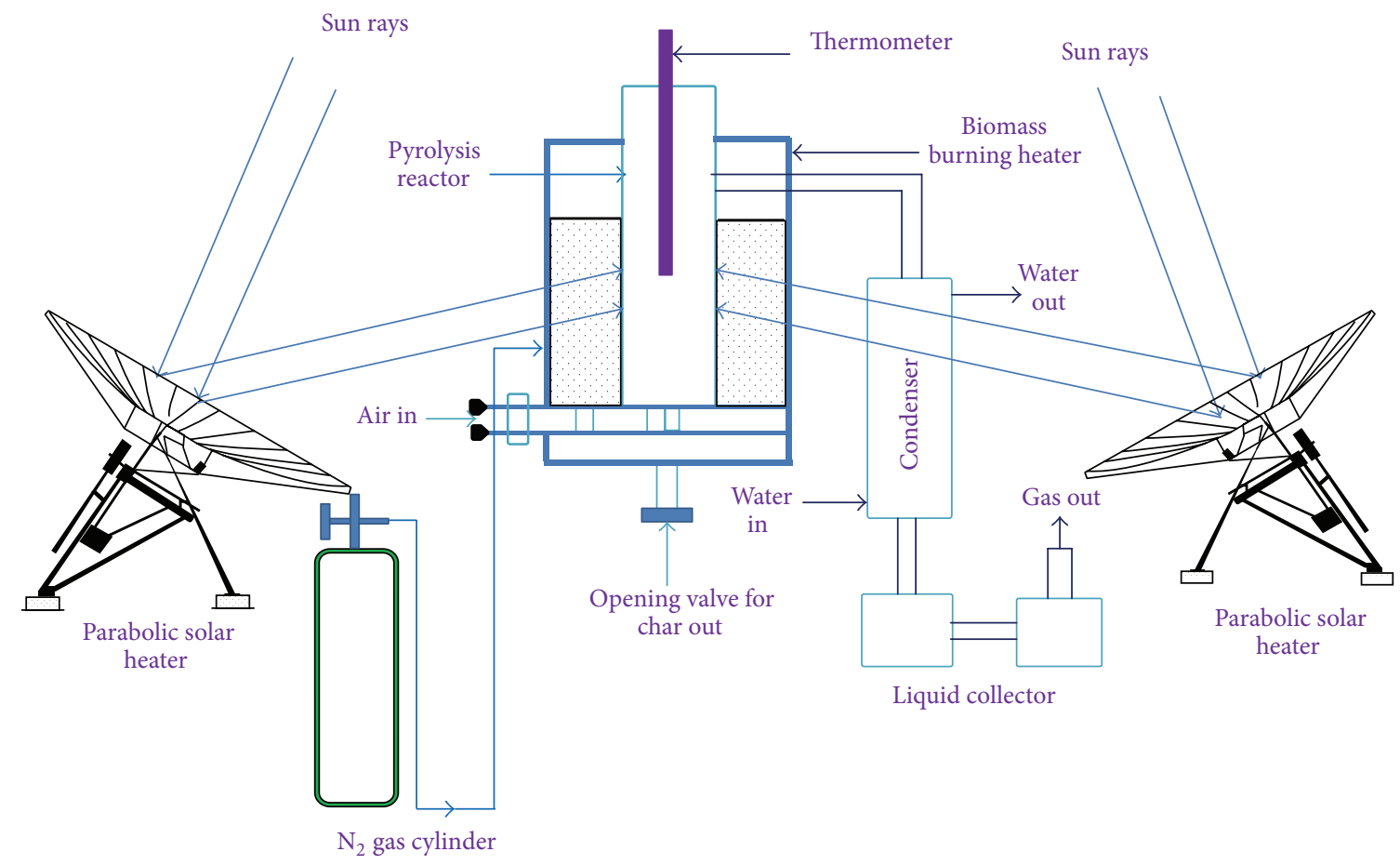

FIGURE 5: Schematic diagram of fixed bed solar assisted pyrolysis system.

TABle 1: Proximate and ultimate analysis of date seed.

\begin{tabular}{lccc}
\hline \multicolumn{2}{c}{ Proximate analysis } & \multicolumn{2}{c}{ Ultimate analysis } \\
Elements & Wt.\% & Elements & Wt.\% \\
\hline Moisture & $5-10$ & Carbon & 84.50 \\
Oil & $7-10$ & Hydrogen & 2.20 \\
Carbohydrates & $55-65$ & Nitrogen & 4.10 \\
Ash & $1-2$ & Oxygen & 9.15 \\
Crude fiber & $10-20$ & Sulfur & 0.04 \\
\hline
\end{tabular}

source for heating the reactor can heat partially the reactor up to $162^{\circ} \mathrm{C}$. The heater is surrounded by asbestoses to minimize heat loss from the heater. Inert atmosphere inside the reactor and flow of the pyrolysis vapor products to the condenser are maintained by supplying nitrogen gas. Finally, condensate (biooil) from pyrolysis vapor is collected in the liquid collectors from condenser whether the noncondensed, unused gas is flared to the atmosphere.

\section{Result and Discussion}

4.1. Product Yield. Pyrolysis liquid (biooil), solid char, and gas are the major products obtained from the pyrolysis of date seed. The product yield of pyrolysis widely varies by different factors, mainly operating temperature, feed particle size, and running time. However, the analysis shows that the maximum (50 wt.\%) liquid oil is found at an operating temperature of $500^{\circ} \mathrm{C}$ for a feed size volume of $0.15 \mathrm{~cm}^{3}$ (quarter of date seed) at a gas flow rate of 6 liters/min with a running time of 120 minutes. The effect of these factors on yield has been described in the study of Joardder et al. [36]. The main objective of this study is to investigate the effect of solar heating on cost and emission not the effect of product yield parameters. However, no apparent variation has been found in product yield quantity due to the incorporation of solar heating system. However, there is a noticeable participation of solar energy to mitigate energy consumed by the system.

4.2. Comparison of Date Seed Oil with Other Biomass Derived Oils and Diesel Fuel. The pyrolysis oil from date seed was analyzed to obtain different physical properties like density, viscosity, flash point, pour point, and GCV and the values were determined by using the standard methods ASTM D189, ASTM D445, ASTM D92, ASTM D97, and ASTM D240, respectively. Density of oil has been found $1042.4 \mathrm{~kg} / \mathrm{m}^{3}$ at $26^{\circ} \mathrm{C}$ and the heating value of oil shows $28.636 \mathrm{MJ} / \mathrm{kg}$. The comparison of characteristics of date seed oil with other oils derived from biomass and diesel is presented in Table 2.

The comparison shows that the density and viscosity of date seed liquid is higher than that of the conventional diesel fuel whether the heating value is lower than diesel. The calorific value is more than other pyrolysis oils except the Mahogany seed oil.

4.3. Feasibility of Solar Assisted Pyrolysis. Since the concept of solar pyrolysis is in embryonic stage, there is no sufficient literature pertaining the comparison of the solar assisted pyrolysis with the conventional fast pyrolysis system. On the basis of primary findings of the proposed pyrolysis system, the following sections are devoted to the feasibility study of this system. The feasibility test of the proposed system has 
TABLE 2: Comparison of date seed oil with other biomass derived oils and diesel fuel.

\begin{tabular}{|c|c|c|c|c|c|c|c|c|c|}
\hline Analysis & $\begin{array}{c}\text { Date seed } \\
\text { oil }\end{array}$ & $\begin{array}{c}\text { Waste paper } \\
\text { oil [37] }\end{array}$ & $\begin{array}{c}\text { Sugarcane } \\
\text { bagasse oil [38] }\end{array}$ & $\begin{array}{c}\text { Jute stick } \\
\text { oil [39] }\end{array}$ & $\begin{array}{c}\text { Plum seed } \\
{[32]}\end{array}$ & $\begin{array}{c}\text { Mahogany } \\
\text { seed [33] }\end{array}$ & $\begin{array}{l}\text { Coconut } \\
\text { seed [34] }\end{array}$ & $\begin{array}{c}\text { Diesel } \\
{[40]}\end{array}$ & $\begin{array}{c}\text { Heavy fuel } \\
{[41]}\end{array}$ \\
\hline $\begin{array}{l}\text { Kinematic viscosity at } \\
26^{\circ} \mathrm{C}(\mathrm{cSt})\end{array}$ & 6.63 & 2.00 & 13.80 & 12.8 & 1.14 & 3.8 & 1.99 & 2.61 & 200 \\
\hline Density $\left(\mathrm{kg} / \mathrm{m}^{3}\right)$ & 1042.4 & 1205 & 1160 & 1224 & 940 & 1525 & 1095.5 & 827.1 & 980 \\
\hline Flash point $\left({ }^{\circ} \mathrm{C}\right)$ & 126 & 200 & 105 & $>70$ & 112 & 60 & $>100$ & 53 & $90-180$ \\
\hline $\mathrm{pH}$ value & - & 1.5 & 2.75 & 2.92 & 3.19 & - & - & - & - \\
\hline HHV (MJ/kg) & 28.636 & 13.10 & 20.72 & 21.09 & 22.4 & 32.4 & 21.40 & 45.18 & $42-43$ \\
\hline
\end{tabular}

TABle 3: Properties of rice husk [42].

\begin{tabular}{|c|c|c|c|c|c|}
\hline \multicolumn{3}{|c|}{ Proximate analysis } & \multicolumn{3}{|c|}{ Ultimate analysis } \\
\hline Elements & Value & Basis & Elements & Value & Basis \\
\hline Moisture (\%) & 11.94 & As received & Carbon (\%) & 38.23 & Dry \\
\hline Ash content (\%) & 14.22 & Dry & Hydrogen (\%) & 5.80 & Dry \\
\hline Volatile matter (\%) & 59.87 & Dry & Nitrogen (\%) & 1.21 & Dry \\
\hline Fixed carbon (\%) & 18.56 & Dry & Oxygen (\%) & 40.50 & Dry \\
\hline LHV (MJ/kg) & 13.16 & As received & Sulfur (\%) & 0.041 & Dry \\
\hline HHV (MJ/kg) & 15.22 & Dry & & & \\
\hline
\end{tabular}

been assessed with comparison of conventional first pyrolysis in terms of energy input, cost of heating, and environmental pollution. To investigate these parameters, the reactor temperature was firstly raised to $162^{\circ} \mathrm{C}$ using solar concentrator and then to $400-600^{\circ} \mathrm{C}$ by external biomass heating.

4.3.1. Energy Input for Heating. Generally, in fast pyrolysis, the reactor is heated up by external (biomass) or internal (electrical) energy source. In other words, significant amount of energy is required to run the reactor for decomposition of feed materials. The effectiveness of the pyrolysis considerably depends on the amount of energy used to complete the decomposition of the feed materials. Therefore, another renewable energy source, such as solar energy inclusion, may reduce the amount of energy that is required in fast pyrolysis system.

It has been found that about $6 \mathrm{~kg}$ of rice husk is required to decompose the date seed of $0.4 \mathrm{~kg}$ in one cycle [36]. The heating value of rice husk varies between 13.16 and $15.22 \mathrm{MJ} / \mathrm{kg}$ as shown in Table 3 [42]. Therefore, considering the lower calorific value of rice husk, it is estimated that the reactor consumes about 78.96 MJ for complete decomposition of date seed in one cycle in fast pyrolysis. On the other hand, assimilation of solar heating system with rice husk heating system reduces the rice husk energy input to $4.056 \mathrm{~kg}$ equivalent to $53.38 \mathrm{MJ}$ as illustrated in Figure 6.

In this proposed pyrolysis system, solar energy can be used partially as renewable source to mitigate the amount of energy input from rice husk burning. However, if the solar concentration can be improved and designed in such a way that it heats up the reactor continuously to raise the temperature around $500^{\circ} \mathrm{C}$, then no conventional energy will be required for heating the reactor.

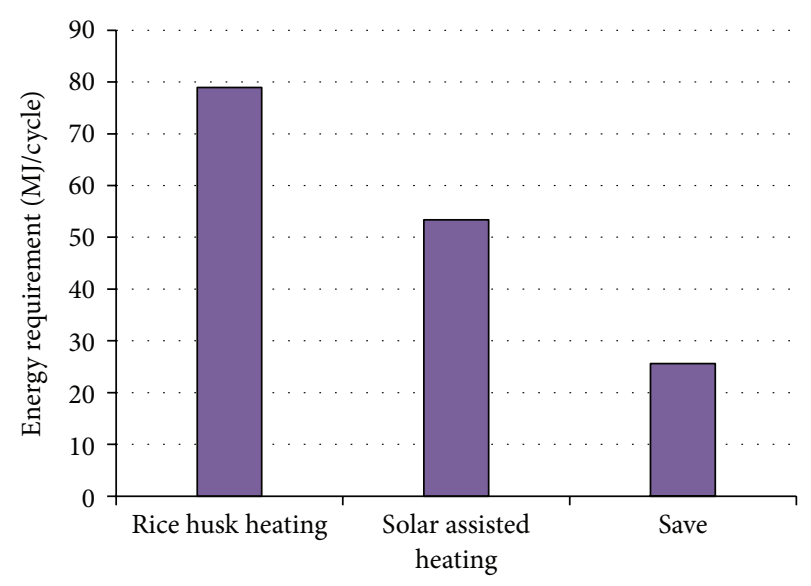

FIGURE 6: Energy consumption from rice husk heating and solar assisted heating.

4.3.2. Environmental Aspect. External or internal heating system in fast pyrolysis uses conventional fuels which in turn produce greenhouse gasses. The open burning of biomass is a significant source of $\mathrm{CO}_{2}, \mathrm{CH}_{4}$, and $\mathrm{N}_{2} \mathrm{O}$, as well as other pollutants such as $\mathrm{NO}_{x}, \mathrm{CO}$, and volatile carbon compounds [43]. This waste gas is one of the prime concerns of the scientists in the twenty-first century. In this work, external biomass (i.e., rice husk) heating system is used in pyrolysis reactor heating. Rice husk contains about $38.23 \%$ carbon which produces almost $1.40 \mathrm{~kg} \mathrm{CO}$ per $\mathrm{kg}$ of rice husk burning as presented in Table 4 .

In addition, it is responsible for significant amount of $\mathrm{SO}_{2}$ and $\mathrm{NO}_{x}$ emission competitive to coal, natural gas, and oil. This leads to adverse effects on environment and causes 
TABLE 4: Amount of $\mathrm{CO}_{2}$ production from various fuels.

\begin{tabular}{lccc}
\hline \multirow{2}{*}{ Fuels } & \multicolumn{2}{c}{ Carbon content } & $\mathrm{CO}_{2}$ emission $(\mathrm{kg} / \mathrm{kg}$ fuel) \\
& $(\%)$ & Reference & 1.40 \\
\hline Rice husk & 38.23 & {$[42]$} & 2.75 \\
Coal & 75.00 & {$[44]$} & 3.12 \\
Natural gas & 85.00 & {$[44]$} & 2.75 \\
Oil & 75.00 & {$[44]$} & \\
\hline
\end{tabular}

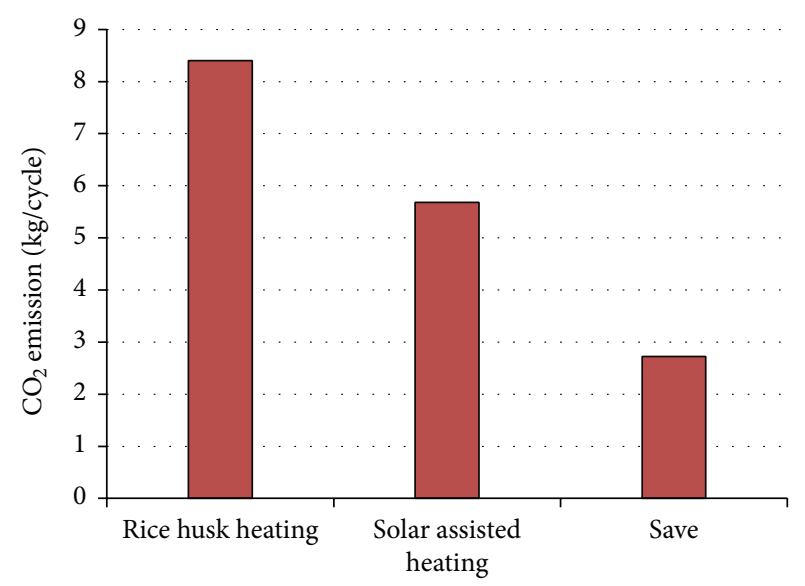

FIGURE 7: Emission from rice husk heating and solar assisted heating.

global warming. Accordingly, it is estimated that the required amount of rice husk in fast pyrolysis produces about $8.40 \mathrm{~kg}$ $\mathrm{CO}_{2}$ in one cycle to raise the temperature up to $500^{\circ} \mathrm{C}$ for optimum yield. In addition, intermittent solar heating along with rice husk heating of the reactor required about $4.056 \mathrm{~kg}$ rice husk responsible for almost $5.68 \mathrm{~kg} \mathrm{CO}$ emission as illustrated in Figure 7 . Therefore, it has been estimated that incorporation of solar heating reduces about $2.72 \mathrm{~kg} \mathrm{CO}$ (32.4\%) emission per cycle.

4.3.3. Cost of Heating System. The proper cost of pyrolysis plant's heating system comprises the estimation of capital costs (installation, fixed) and operating costs (fuel, maintenance, labor). As our comparison is in laboratory level, the actual cost analysis with these parameters is not possible to compare with fast pyrolysis. Therefore, only the cost of fuel in both cases is considered for heating the reactor. Rice husk is commonly used in cooking, parboiling, tea stall, duck feeding, and so forth, in Bangladesh. Recently, rice husk based power plants have been established in Bangladesh. For this reason, price of rice husk is increasing and it is sold at a price of 0.1 USD per $\mathrm{kg}$ in rural areas in Bangladesh. Consequently, the total cost of rice husk heating in one cycle for optimum yield condition is estimated to be about 0.6 USD.

On the contrary, solar heating incorporation reduces the fuel cost to 0.41 USD per cycle as shown in Figure 8. Therefore, it saves about $1.944 \mathrm{~kg}$ of rice husk of price 0.19 USD per cycle which can be used in other purposes. Though the small scale production of biooil is relatively costly, the mass production will reduce the production cost

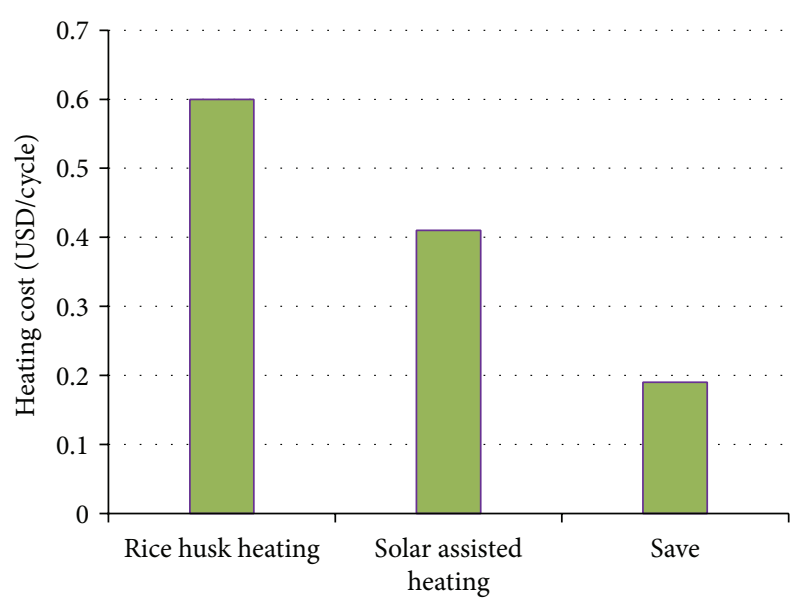

FIGURE 8: Cost of rice husk heating and solar assisted heating.

by incorporating huge amount of solar energy. If it is possible to use complete solar fast pyrolysis, then fuel cost will be reduced to zero.

It has been found from the above discussion that introduction of the solar heating system in pyrolysis can be a promising approach. The associated solar system reduces heating cost of the pyrolysis process. Further investigation is being carried out in order to find out energy efficiency and cost optimization.

\section{Conclusion}

The pyrolytic product yields and liquid product composition of the presented study prove that solar-biomass pyrolysis technology is an efficient and effective method of heating. The optimum liquid yields conditions for the reactor system are operating temperature $500^{\circ} \mathrm{C}$ and size volume of $0.11-0.2 \mathrm{~cm}^{3}$ (quarter of date seed) at a gas flow rate of 5 liters/min with a running time of 120 minutes; liquid production is found to be the maximum ( $50 \mathrm{wt} \%)$ of the dry feedstock. From this study, it is found that the oil is heavy in nature with moderate viscosity and heating value. The relevance of solar heating is clearly supported by the current findings. It has been also found that solar energy would contribute to reduction of both $\mathrm{CO}_{2}$ emission and fuel cost by $32.4 \%$. In general, therefore, it seems that solar-biomass pyrolysis is a potential candidate of renewable energy that can play a pivotal role in reduction of employment problem, environmental hazard, and fuel crisis in Bangladesh. The issue of proper solar system design is a prospective option of the production of renewable energy. As this concept is at embryonic stage, there remains a huge room for further investigation.

\section{Conflict of Interests}

The authors declare that there is no conflict of interests regarding the publication of this paper. 


\section{References}

[1] P. K. Halder, M. U. H. Joardder, M. R. A. Beg, N. Paul, and I. Ullah, "Utilization of Bio-Oil for cooking and lighting," Advances in Mechanical Engineering, vol. 2012, Article ID 190518, 5 pages, 2012.

[2] Titas Gas Transmission and Distribution Company (TGTDC), 2011, http://www.bloomberg.com/apps.

[3] Barapukuria Coal Mining Company Limited (BCMCL), Bangladesh, 2011, http://www.bcmcl.org.bd.

[4] "Bangladesh Petroleum Corporation (BPC)," 2011, http://www .mof.gov.bd.

[5] A. T. Marshall and J. M. Morris, "A watery solution and sustainable energy parks," CIWM Journal, pp. 22-23, 2006.

[6] M. N. Islam, "Energy context in Bangladesh," in Photovoltaic Technology for Bangladesh, A. K. M. Islam and D. G. Infield, Eds., University of Engineering and Technology, Loughborough University; Dhaka, Bangladesh, Loughborough, UK, 2001.

[7] Bangladesh Power Development Board (BPDB), http://www .bpdb.gov.bd/bpdb/.

[8] D. Mohan, C. U. Pittman Jr., and P. H. Steele, "Pyrolysis of wood/biomass for bio-oil: a critical review," Energy and Fuels, vol. 20, no. 3, pp. 848-889, 2006.

[9] J. A. Caballero, R. Front, A. Marcilla, and J. A. Conesa, "Characterization of sewage sludges by primary and secondary pyrolysis," Journal of Analytical and Applied Pyrolysis, vol. 40-41, pp. 433-450, 1997.

[10] A. V. Bridgwater and S. A. Bridge, "A review of biomass pyrolysis and pyrolysis technologies," in Biomass Pyrolysis Liquids Upgrading and Utilization, A. V. Bridgwater and G. Grassi, Eds., pp. 11-92, Elsevier Applied Science, London, UK, 1991.

[11] D. Radleinand and A. Quignard, "A short historical review of fast pyrolysis of biomass," Oil and Gas Science and Technology, vol. 68, no. 4, pp. 765-783, 2013.

[12] S. Jung, B. Kang, and J. Kim, "Production of bio-oil from rice straw and bamboo sawdust under various reaction conditions in a fast pyrolysis plant equipped with a fluidized bed and a char separation system," Journal of Analytical and Applied Pyrolysis, vol. 82 , no. 2, pp. 240-247, 2008.

[13] A. Demirbas, "Effects of temperature and particle size on biochar yield from pyrolysis of agricultural residues," Journal of Analytical and Applied Pyrolysis, vol. 72, no. 2, pp. 243-248, 2004.

[14] M. Asadullah, M. A. Rahman, M. M. Ali et al., "Production of bio-oil from fixed bed pyrolysis of bagasse," Fuel, vol. 86, no. 16, pp. 2514-2520, 2007.

[15] M. Asadullah, M. Anisur Rahman, M. Mohsin Ali et al., "Jute stick pyrolysis for bio-oil production in fluidized bed reactor," Bioresource Technology, vol. 99, no. 1, pp. 44-50, 2008.

[16] L. Fagernas, "Chemical and physical characterization of biomass-based pyrolysis oils: literature review," Technical Research Centre of Finland, 1995.

[17] M. A. H. Mondal and M. Denich, "Assessment of renewable energy resources potential for electricity generation in Bangladesh," Renewable and Sustainable Energy Reviews, vol. 14, no. 8, pp. 2401-2413, 2010.

[18] A. H. Mondal and M. Denich, "Hybrid systems for decentralized power generation in Bangladesh," Energy for Sustainable Development, vol. 14, no. 1, pp. 48-55, 2010.

[19] B. van der Zwaan and A. Rabl, "Prospects for PV: a learning curve analysis," Solar Energy, vol. 74, no. 1, pp. 19-31, 2003.
[20] M. U. H. Joardder, M. N. Islam, M. S. Uddin, and M. Hasan, "Pyrolysis of pine seed for liquid oil production," in Proceedings of the 4th KKU International Engineering Conference (KKUIENC '12), Khon Kaen, Thailand, May 2012.

[21] M. N. Islam and F. N. Ani, "Characterization of bio-oil from palm shell pyrolysis with catalytic upgrading," in Proceedings of the World Renewable Energy Congress, pp. 1977-1999, Elsevier Science, 1998.

[22] M. N. Islam and M. R. A. Beg, "The fuel properties of pyrolysis liquid derived from urban solid wastes in Bangladesh," Bioresource Technology, vol. 92, no. 2, pp. 181-186, 2004.

[23] M. R. Islam, M. Parveen, and H. Haniu, "Properties of sugarcane waste-derived bio-oils obtained by fixed-bed fire-tube heating pyrolysis," Bioresource Technology, vol. 101, no. 11, pp. 4162-4168, 2010.

[24] M. R. Islam, H. Haniu, and J. Fardoushi, "Pyrolysis kinetics behavior of solid tire wastes available in Bangladesh," Waste Management, vol. 29, no. 2, pp. 668-677, 2009.

[25] M. R. Islam, H. Haniu, and M. R. Alam Beg, "Liquid fuels and chemicals from pyrolysis of motorcycle tire waste: product yields, compositions and related properties," Fuel, vol. 87, no. 1314, pp. 3112-3122, 2008.

[26] M. R. Islam, M. S. H. K. Tushar, and H. Haniu, "Production of liquid fuels and chemicals from pyrolysis of Bangladeshi bicycle/rickshaw tire wastes," Journal of Analytical and Applied Pyrolysis, vol. 82, no. 1, pp. 96-109, 2008.

[27] M. N. Islam and M. R. A. Beg, "Fixed bed pyrolysis of scrap tyre for liquid fuel production," International Energy Journal, vol. 5, no. 1, pp. 11-18, 2004.

[28] M. N. Islam and F. N. Ani, "Liquid oil from fluidized bed pyrolysis of rice husk waste and its characterization," RERIC International Energy Journal, vol. 20, no. 1, pp. 55-65, 1998.

[29] M. N. Islam and F. N. Ani, "Techno-economics of rice husk pyrolysis, conversion with catalytic treatment to produce liquid fuel," Bioresource Technology, vol. 73, no. 1, pp. 67-75, 2000.

[30] M. N. Islam, S. M. N. Hoque, M. M. Karim, and H. Khanam, "Fixed bed pyrolysis of the hay of catkin for liquid oil," in Proceedings of the 12th Annual Paper Meet, IEB, Dhaka, Bangladesh, 2008.

[31] M. N. Islam, M. Rahman, M. A. Shamim, and M. S. Hossain, "Fixed bed pyrolysis of linseed solid waste for liquid oil production," in Proceedings of the 12th Annual Paper Meet, IEB, Dhaka, Bangladesh, 2008.

[32] M. Uddin, M. U. H. Joardder, and M. N. Islam, "Design and construction of fixed bed pyrolysis system and plum seed pyrolysis for bio-oil production," International Journal of Advanced Renewable Energy Research, vol. 7, no. 1, pp. 405-409, 2012.

[33] M. Kader, M. U. H. Joardder, M. R. Islam, B. K. Das, and M. M. Hasan, "Production of liquid fuel and activated carbon from mahogany seed by using pyrolysis technology," in Proceedings of the International Conference on Mechanical Engineering (ICME '11), Bangladesh University of Engineering and Technology, Dhaka, Bangladesh, December 2011.

[34] M. U. H. Joardder, M. R. Islam, and M. R. A. Beg, "Pyrolysis of coconut shell for bio-oil," in Proceedings of the International Conference on Mechanical Engineering (ICME '11), Bangladesh University of Engineering and Technology, Dhaka, Bangladesh, 2011.

[35] M. R. Islam, M. U. H. Joardder, S. M. Hasan, K. Takai, and H. Haniu, "Feasibility study for thermal treatment of solid tire 
wastes in Bangladesh by using pyrolysis technology," Waste Management, vol. 31, no. 9-10, pp. 2142-2149, 2011.

[36] M. U. H. Joardder, M. S. Uddin, and M. N. Islam, "The utilization of waste date seed as bio-oil and activated carbon by pyrolysis process," Advances in Mechanical Engineering, vol. 2012, Article ID 316806, 6 pages, 2012.

[37] M. N. Islam, M. R. A. Beg, and M. R. Islam, "Pyrolytic oil from fixed bed pyrolysis of municipal solid waste and its characterization," Renewable Energy, vol. 30, no. 3, pp. 413-420, 2005.

[38] M. R. Islam and M. N. Islam, "The fixed bed pyrolysis of sugarcane bagasse for liquid fuel production," in Proceedings of the International Conference on Mechanical Engineering (ICME '03), pp. 26-28, Dhaka, Bangladesh, 2003.

[39] M. R. Islam, M. N. Nabi, and M. N. Islam, "Characterization of biomass solid waste for liquid fuel production," in Proceedings of the 4th International Conference on Mechanical Engineering (lCME '01), pp. 77-82, Bangladesh, 2001.

[40] R. G. Andrews and P. C. Patniak, "Feasibility of utilizing a biomass derived fuel for industrial gas turbine applications," in Bio-Oil Production and Utilization, A. V. Bridgwater and E. N. Hogan, Eds., pp. 236-245, CPL Press, Berkshire, UK, 1996.

[41] F. Rick and U. Vix, "Product standards for pyrolysis products for use as fuel in industrial firing plants," in Biomass Pyrolysis Liquids Upgrading and Utilization, A. V. Bridgwater and and G. Grassi, Eds., Elsevier Applied Science, London, UK, 1991.

[42] T. Chungsangunsit, S. H. Gheewala, and S. Patumsawad, "Environmental assessment of electricity production from rice husk: a case study in Thailand," International Energy Journal, vol. 6, no. 1, pp. 347-355, 2005.

[43] M. Cheng, C. Horng, Y. Su, L. Lin, Y. Lin, and C. C.-K. Chou, "Particulate matter characteristics during agricultural waste burning in Taichung City, Taiwan," Journal of Hazardous Materials, vol. 165, no. 1-3, pp. 187-192, 2009.

[44] Biomass Energy Centre, "Carbon emissions of different fuels," 2014, http://www.biomassenergycentre.org.uk/portal/page pageid=75,163182\&_dad=portal\&_schema $=$ PORTAL. 

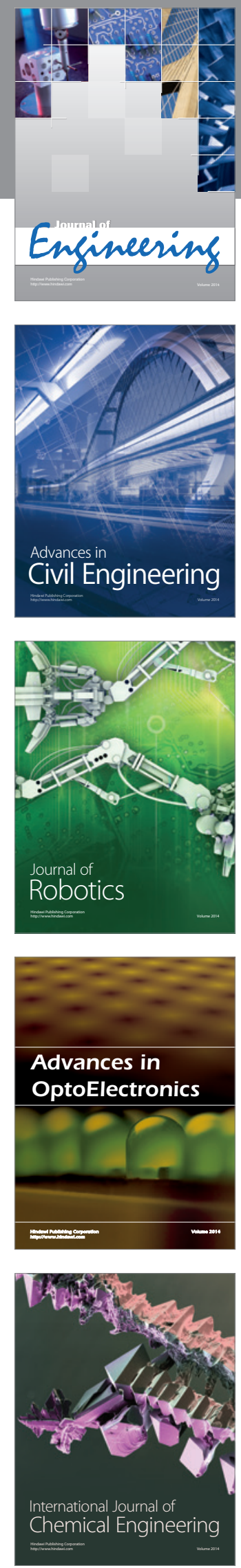

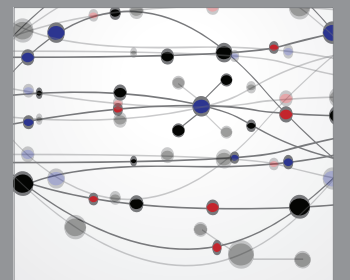

The Scientific World Journal
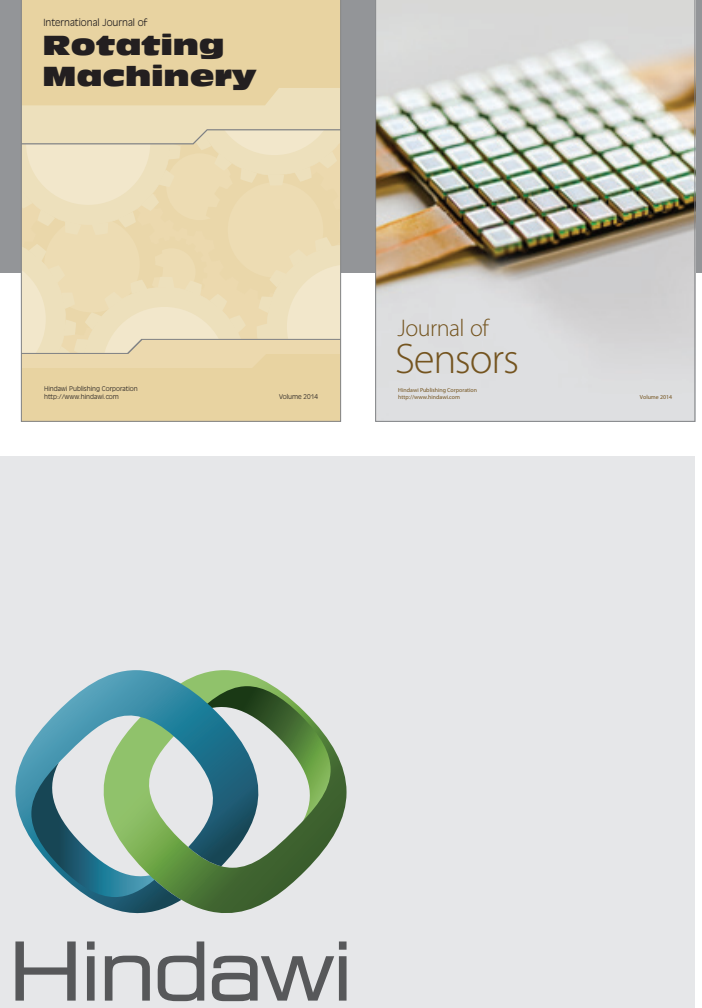

Submit your manuscripts at http://www.hindawi.com
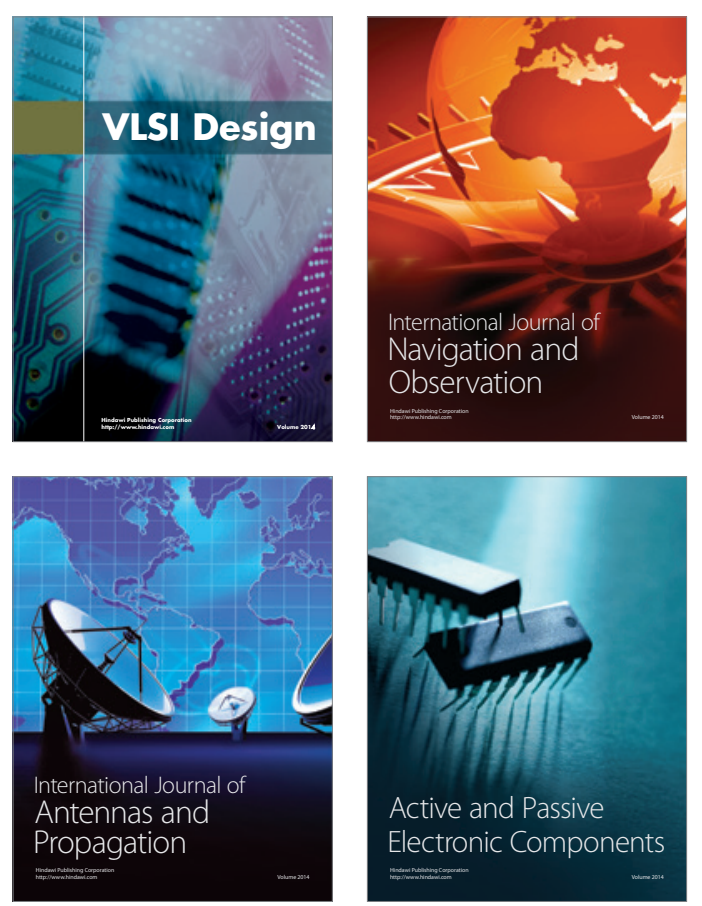
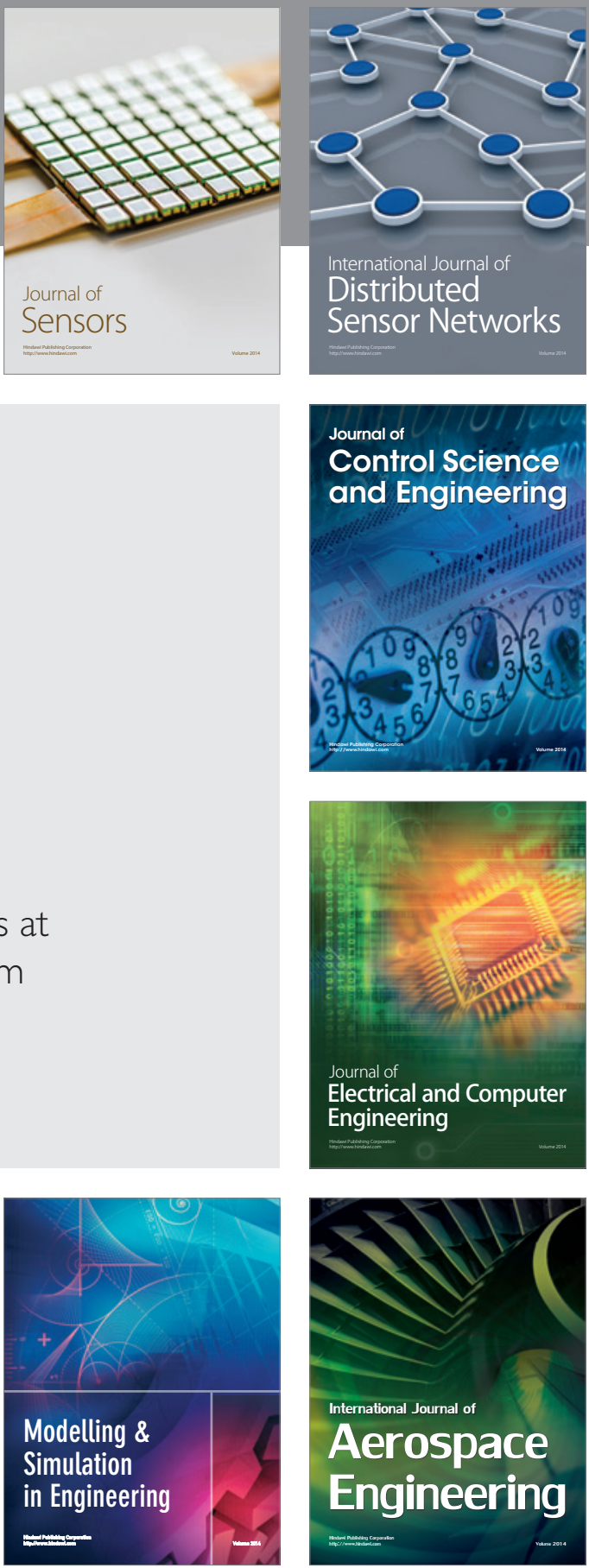

Journal of

Control Science

and Engineering
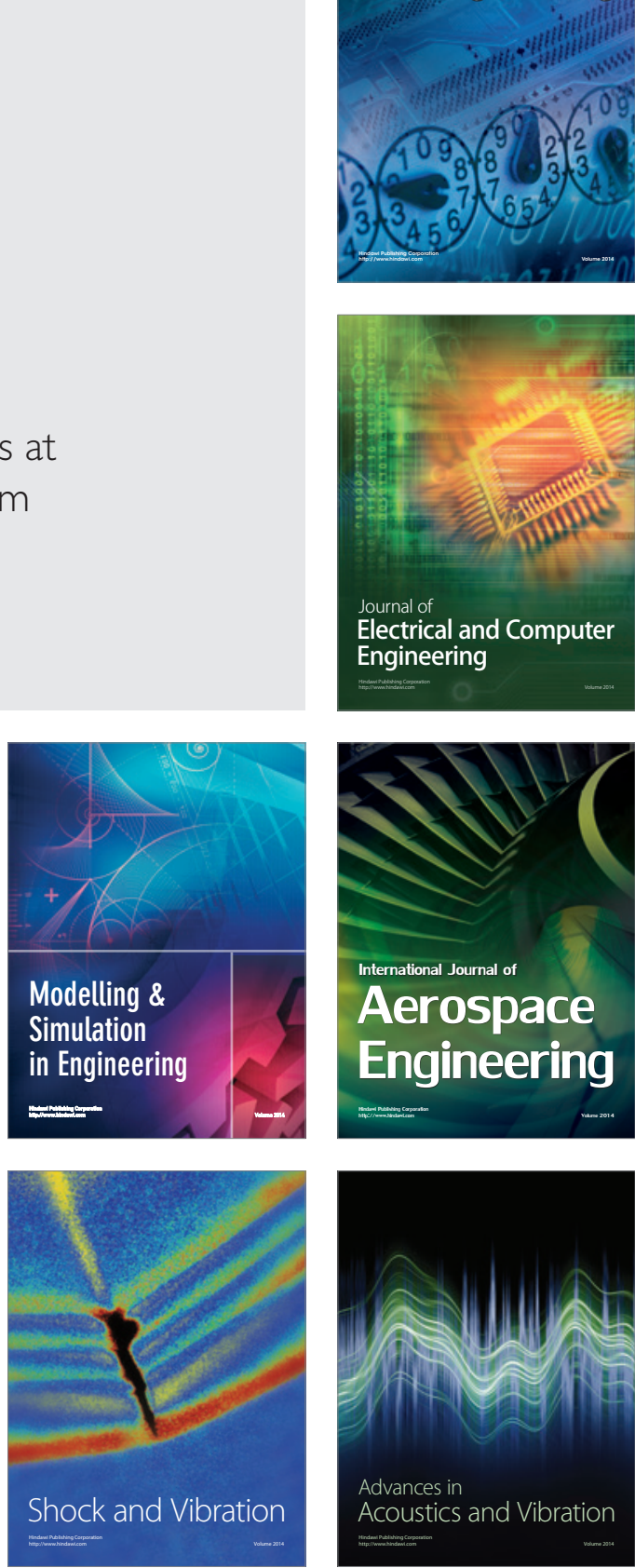